\title{
Analisis Faktor-faktor Produksi pada Peternakan Sapi Perah Ompie Farm di Kabupaten Tanah Datar
}

\author{
Analysis of Production Factors on Ompie Dairy Farm \\ at Tanah Datar Regency
}

\author{
Syafril, R. Wati, dan A.I. Osvaldo
}

Fakultas Peternakan Universitas Andalas

Kampus Unand Limau Manis Padang 25163

E-mail: rahmi.unand@gmail.com

(Diterima: 14 Oktober 2010; Disetujui: 12 Januari 2011)

\begin{abstract}
The research purpose was analyzed the utilization of production factors in dairy cow farming in economies of scale at Ompie dairy cow farming in Tanjung Bonai village, North of Lintau Buo subdistrict, Tanah Datar regency. The samples were 18 lactating dairy cows. Data obtained through case study by observing and calculated the consumption of grass and concentrate as well as the lactating month and the cow's weight directly, and interviewed Farm's caretaker. Production factors estimated by using ordinary least square by using SPSS 17. Result shown, production function $Y=0,0012 \mathrm{H1}, 671 \mathrm{~K} 0,405 \mathrm{M}-0,187 \mathrm{~W} 0,119$ was obtained. $R$ Square test determination, coefficient (R2) was 0.721 , which was means $71,2 \%$ of production variation can be explained through green food variable, concentrate, month of lactation, and different cows' weight. The $F$ test showed that overall, independent variables has significant impact on milk production $(P<0,01)$. The t test result showed that green foods variable and month of lactation has real impacts on level of trust $99 \%$ while concentrate and cow's weight did not have significant impact. This farm is experiencing increasing return to scale which means increasing the amount of input will generate additional output with bigger proportion. We can observe this on Ebivalue of 2,076.
\end{abstract}

Keywords: Production factors, dairy cow, cobb douglas, efficiency

\section{PENDAHULUAN}

Kabupaten Tanah Datar merupakan salah satu daerah sentral pengembangan ternak sapi perah. Populasi sapi perah di Kabupaten Tanah Datar memiliki urutan ketiga setelah Kota Padang Panjang dan Kota Padang. Pada tahun 2007 populasi sapi perah di Kabupaten Tanah Datar berjumlah 112 ekor, Kota Padang Panjang berjumlah 276 ekor dan Kota Padang 162 ekor (Dinas Peternakan Propinsi Sumatera Barat, 2008).

Pada awalnya Petemakan ini menjalankan usahanya untuk penggemukan sapi, namun pada tahun 2005 Peternakan tersebut memfokuskan usahanya pada usaha sapi perah, karens menurut pemilik perusahaan bahwa usaha sapi perah lebih menguntungkan dibandingkan usaha penggemukan.

Produksi susu pada Peternakan Ompie Farm selama tiga tahun terakhir setiap bulannya rata-rata $2.252,5$ liter. Sudono et al. (2003) menyatakan bahwa sapi perah di Indonesia mampu memproduksi susu rata-rata 10 liter/ekor/hari. Produksi susu pada Ompie Farm masih dibawah dari produksi yang diharapkan, yakni rata-rata 5 - 6 liter per ekor hari. Nilai ini mendeskripsikan bahwa belum optimalnya produksi susu pada perusahaan ini.

Peningkatan produksi usaha peternakan sangat tergantung ke pada penggunaan faktorfaktor produksi tersebut. Masalah alokasi sumberdaya ini berkaitan erat dengan keuntungan yang dicapai. Besar kecilnya keuntungan yang diperoleh akan sangat ditentukan oleh nilai jual hasil produksi dan biaya produksi yang dikeluarkan. Keuntungan maksimum dicapai apabila semua faktor produksi telah digunakan secara optimal (Mandaka dan Parulian, 2005)

Untuk dapat menganalisa penggunaan faktorfaktor produksi dengan baik dibutuhkan pengetahuan tentang konsep hubungan antara input(faktor produksi) dengan outputyang dihasilkan dimana hubungan tersebut dinamakan 
dengan fungsi produksi. Berdasarkan latar belakang tersebut, maka penulis tertarik melakukan penelitian dengan judul "Analisis Penggunaan Faktor-Faktor Produksi pada Peternakan Sapi Perah Ompie Farm di Nagan Tanjung Bonai Kecamatan Lintau Buo Utara Kabupaten Tanah Datar". penelitian ini bertujuan untuk:

1. Mengetahui penggunaan faktor-faktor produksi pada Petemakan Sapi Perah Ompie Farm.

2. Mengetahui efisiensi penggunaan faktorfaktor produksi pada pemeliharaan sapi perah Ompie Farm.

3. Mengetahui ekonomi skala usaha pada Petemakan Sapi Perah Ompie Farm.

\section{MATERI DAN METODE}

Penelitian ini dilaksanakan pada Peternakan Ompie Farm di Kecamatan Lintau Buo Utara, Kabupaten Tanah Datar. Metode yang digunakan dalam penelitian ini adalah metode studi kasus (case study).

Data yang digunakan dalam penelitian ini adalah data cross section yaitu data yang dikumpulkan dalam suatu periode tertentu. Sedangkan analisa data yang digunakan adalah analisis deskriptif kuantitatif yang dilakukan untuk mendapatkan model fungsi produksi dan efisiensi penggunaan faktor-faktor produksi pada pemeliharaan sapi perah. Diduga ada tiga vaniabel utama yang mempengaruhi produksi sapi perah yaitu: jumlah pakan yang dihabiskan yang terdiri dari hijauan dan konsentrat, bulan laktasi dan berat badan sapi.

\section{Model fungsi produksi}

Tujuan utama dalam proses produksi pada umumnya adalah untuk memperoleh keuntungan maksimum. Keuntungan akan mencapai kondisi maksimum apabila produksi berjalan secara efisien. Penentuan efisiensi produksi dapat dilakukan setelah fungsi produksi diketahui. Fungsi produksi menggambarkan hubungan fisik antara input dan output melalui persamaan: $Y=f$ (x) (Busboom et al., 1999; Ferson et al., 2003; Sureshetal.,2008).

Model fungsi produksi yang dipakai adalah model fungsi produksi Cobb Douglas karena model fungsi produksi ini relatif lebih sederhana dibandingkan dengan model fungsi produksi lainnya (Simatupang, 1988). Menurut Soekartawi (1994), fungsi produksi adalah hubungan fisik antara masukan produksi (input) dan keluaran produksi (output). Dalam bentuk matematika fungsi produksi dapat ditulis sebagai berikut:

$$
Y=f\left(X, X_{2}, \ldots \ldots X\right)
$$

\section{Dimana :}

$Y=$ Hasil produksi fisik

$X_{p}, X_{2} \ldots X_{s}=$ produksi yang digunakan

Suryana (1987) menjelaskan beberapa keterbatasan yang dimiliki oleh fungsi CobbDouglas yaitu:

1. Dugaan elastisitas permintaan harga sendiri akan selalu elastis.

2. Dugaan elastisitas silang akan selalu negatif, sehingga mempunyai arti bahwa hubungan antar input selalu bersifat komplementer.

3. Dugaan elastisitas permintaan dari input yang diduga dengan fungsi tersebut terhadap salah satu input variabel akan sama besarnya, dan terhadap input tetap akan mempunyai tanda dan besaran yang sama,

4. Dugaan elastisitas permintaan input terhadap perubahan harga produk (output) akan selalu elastis.

Pada penelitian ini terdapat empat variabel yang dimasukkan sebagai variabel yang mempengaruhi produksi susu yaitu :

1. Makanan hijauan yaitu banyaknya hijauan yang dikonsumsi sapi selama satu minggu yang dinyatakan dalam $\mathrm{Kg} /$ ekor/minggu.

2. Makanan konsentrat yaitu jumlah konsentrat yang dikonsumsi sapi dalam satu minggu yang dinyatakan dalam $\mathrm{Kg} /$ ekor/minggu.

3. Bulan laktasi yang menyatakan bulan ke-n dari seekor sapi yang sedang diamati.

4. Berat badan sapi yang menyatakan ukuran berat badan dari seekor sapi yang dinyatakan dengan $\mathrm{Kg}$. Data berat badan sapi diperoleh dengan cara menghitung lingkar dada sapi dengan menggunakan pita ukur. Pengukuran lingkar dada sapi dimulai dari pundak sampai dasar dada di belakang siku dan tulang belikat. Menurut Sudono et al., (1980) berat badan sapi dapat diduga dengan menggunakan tabel berat badan sapi 
dan bisa juga dengan menggunakan rumus Schoorl:

\section{Bobot Badan $\mathrm{Sapi}=$ \\ $\frac{\text { Lingkar Dada }+22)^{2}}{100}$}

Dari variabel diatas maka fungsi produksi yang hendak diduga adalah:

$$
\mathrm{Y}=\mathrm{boH} \mathrm{H}^{\mathrm{s1}} \mathrm{K}^{32} \mathrm{M}^{\mathrm{bl}} \mathrm{W}^{\mathrm{b}}
$$

Keterangan :

$\mathrm{Y}=$ Jumlah produksi susu perekor sapi yang sedang laktasi dalam satu minggu dalam satuan liter.

$\mathrm{H}=$ Jumlah hijauan yang diukur dengan menimbang yang dikonsumsi dalam satu hari $(\mathrm{Kg})$ dan dihitung dalam satu minggu.

$\mathrm{K}=$ Jumlah konsentrat yang diukur dengan menimbang yang dikonsumsi da $1 \mathrm{a} \mathrm{m}$ waktu sehari $(\mathrm{Kg})$ dihitung dalam satu minggu.

$\mathrm{M}=$ Bulan laktasi yang bernilai satu untuk bulan laktasi pertama, dua untuk bulan laktasi kedua dan seterusnya.

$\mathrm{W}=$ Berat badan sapi yang dihitung dalam satuan $\mathrm{Kg}$.

bo $=$ Intersep

$\mathrm{b} 1, \mathrm{~b} 2, \mathrm{~b} 3, \mathrm{~b} 4,=$ Besaran yang hendak diduga $=$ Elastisitas produksi.

Untuk menduga persamaan diatas maka diubah menjadi bentuk linear dengan cara melogaritmakan persamaan diatas.

$\log Y=\log b o+b 1 \log H+b 2 \log K+b 3 \log M$ $+\mathrm{b} 4 \log W$

\section{Evaluasi model}

Untuk memastikan bahwa penduga yang didapatkan dari hasil pendugaan model bersifat valid, maka dilakukan evaluasi terhadap model yang didapat berupa evaluasi secara statistik dan evaluasi pengujian asumsi klasik.

Evaluasi statistik dilakukan untuk melihat apakah secara statistik model dapat diterima, akan ada tiga pengujian yaitu uji $F$, uji $R^{2}$ dan uji t. uji $F$ dilakukan untuk melihat apakah faktor produksi secara bersama-sama berpengaruh nyata terhadap produksi. Uji $\mathrm{R}^{2}$ dilakukan untuk melihat seberapa besar pengaruh variabel independen terhadap vanabel dependen. Uji t dilakukan untuk melihat apakah masing - masing faktor produksi secara parsial berpengaruh nyata terhadap produksi susu.

Pada pengolahan secara regresi berganda dengan software/ program statistik pengujian dapat langsung dilakukan dengan melihat nilai signifikan yang dihasilkan. Apabila nilai signifikan pada analisis ANOVA lebih kecil dari 0,05 dikatakan penggunaan faktor produksi secara bersama-sama berpengaruh nyata terhadap produksi pada $\alpha 5 \%$, sebaliknya jika nilai signifikan besar dari 0,05 berarti penggunaan faktor produksi secara bersama-sama tidak berpengaruh nyata. Apabila nilai signifikasi yang dihasilkan untuk uji t masing - masing faktot produksi lebih kecil dari 0,05 dikatakan faktor produksi yang bersangkutan secara parsial berpengaruh nyata terhadap produksi susu pada $\alpha 5 \%$.

Untuk melihat apakah variabel yang didapat valid dilakukan pengecekkan dengan asumsi klasik. Evaluasi asumsi klasik dilakukan untuk memastikan bahwa model yang diduga bebas dari permasalahan multikolineariti, autokolerasi dan hetero-skedastisitas.

\section{Pengujian effisiensi ekonomi penggunaan faktor-faktor produksi dan ekonomi skala usaha}

Efisiensi penggunaan faktor-faktor produksi. Tingkat efisiensi produksi dapat dilihat secara teknis dan ekonomis. Efisiensi teknis dapat ditunjukkan olch hubungan fisik antar faktor faktor produksi dengan output yang dihasilkan. Efisiensi teknis akan tercapai apabila untuk menghasilkan output tertentu digunakan kombinasi input yang terkecil. Selanjutnya, efísiensi ekonomis dapat dicapai apabila dalam menghasilkan output digunakan biaya terendah (Hadley, 2006; Vincze dan Tenk, 2007).

$$
\text { Jika nilai } \frac{N P M X_{n}}{B K M X_{n}}=1 \text {, }
$$

maka terjadi efisiensi penggunaan faktor-faktor produksi.

$$
\text { Jika nilai } \frac{N P M X_{n}}{B K M X_{n}} \neq 1 \text {, }
$$

efisiensi penggunaan faktor-faktor produksi tidak terjadi. 
Tabel 1. Hasil pendugaan model fungsi produksi

\begin{tabular}{|c|c|c|}
\hline Variabel Penjelas & Koofesien Regresi & Nilai Signifikan Untuk Uji t \\
\hline Konstanta: & $-2,900$ & 0,194 \\
\hline Hijauan & 1,671 & 0,009 \\
\hline Konsentrat & 0,405 & 0,479 \\
\hline Bulan Laktasi & $-0,187$ & 0,000 \\
\hline Berat Tubuh & 0,119 & 0,667 \\
\hline Koofesien Determinasi & & 0,721 \\
\hline Nilai F Hitung & & 8,400 \\
\hline Nilai Signifikan Uji F & & 0,001 \\
\hline Nilai D - W & & 1,977 \\
\hline Standar Error & & 0,03634 \\
\hline
\end{tabular}

Sumber : Penelitian 2009 (Diolah)

Ekonomi Skala Usaha. Pada besaran fungsi produksi Cobb Douglas sekaligus menunjukkan tingkat skala usaha (Soekartawi, 1994).

Jika $\sum b i=1$, ekonomi skala usaha terjadi

Jika $\sum$ bi $A$, ekonomi skala usaha tidakterjadi.

Dimana:

$\Sigma b i=\mathrm{bl}+\mathrm{b} 2+\mathrm{b} 3+\mathrm{b} 4=$ Elastisitas produksi.

\section{HASIL DAN PEMBAHASAN}

\section{Pendugaan model fungsi produksi sapi potong}

Hasil pendugaan model fungsi produksi ditampilkan pada Tabel 1. Nilai D-W adalah 1,977 yang berarti fungsi produksi yang ada bebas dari kasus autokorelasi, ini sesuai dengan pendapat (1994), yang menyatakan jika nilai D - W berkisar antara -2 dan +2 menandakan model tidak terjadi kasus autokorelasi.

Model fungsi produksi yang digunakan bebas dari kasus multikolineritas, Dari hasil pengujian tersebut tampak bahwa tolerance value lebih besar dari 0,1 atau mendekati angka 1 dengan nilai VIF (Variance Inflation Factor) berkisar diantara 1 , ini menunjukkan bahwa tidak terjadi hubungan linier diantara variabel-varibel bebas dalam model regresi.

Hal ini sesuai dengan pendapat Prastito (2004), yang menyatakan bahwa regresi yang bebas dari multikolinearitas ditandai dengan nilai VIF berkisar angka 1 dannilai tolarence berkisar angka 1 .

Dari hasil deteksi kasus heteroskidastisitas juga dapat disimpulkan bahwa model bebas dari kasus heteroskidastisitas dimana titik-titik menyebar 5 ecara acak dan tersebar baik di atas dan di bawah angka nol pada sumbu Y. Dengan demikian dapat disimpulkan bahwa pa-rameter yang didapat adalah valid.

Dari nilai signifikan uji F (ANOVA) sebesar 0,001 menunjukan bahwa secara bersama - sama variabel jumlah hijauan dan konsentrat yang dikonsumsi setiap ekor sapi serta bulan laktasi dan berat tubuh sapi berpengaruh nyata pada $\alpha 1 \%(\mathrm{p}<0,01)$. Nilai koofesien determinasi model $\left(R^{2}\right)$ sebesar 0,721 yang berarti variasi jumlah produksi susu pada setiap sapi sebesar $72,1 \%$ dapat dijelaskan oleh variabel jumlah hijauan yang dikonsumsi, jumlah konsentrat yang dikonsumsi, bulan laktasi dan berat badan dari setiap sapi.

$\mathrm{Hal}$ ini berarti $27,9 \%$ perbedaaan tingkat produksi dari setiap sapi disebabkan oleh faktor lain yang tidak dimasukkan ke dalam model pada penelitian ini. Banyak variabel yang menentukan tingkat produksi pada sapi perah sebagaimana yang dijelaskan oleh Bakar (1992), bahwa faktor yang mempengaruhi produksi susu adalah sifat keturunan, lama bunting, masa laktasi, masa kering kandang, ukuran sapi, birahi, umur, frekuensi pemerahan, selang beranak, makanan dan tatalaksana serta pengaruh penyakit.

Dari hasil uji t diketahui bahwa dari empat variabel penjelas yang dimasukkan ke model hanya dua variabel parsial yang berpengaruh nyata terhadap jumlah produksi susu yaitu variabel jumlah 
hijauan yang dikonsumsi dengan nilai signifikan sebesar 0,009 dan bulan laktasi dengan nilai signifikan sebesar 0,000 pada tingkat kepercayaan $99 \%$ dimana nilai signifikan untuk variabel tersebut lebih kecil dari $1 \%(0,01)$. Sedangkan veriabel konsentrat dan berat tubuh secara statistik tidak berpengaruh nyata terhadap tingkat produksi dimana nilai signifikannya lebih besar dari 0,05 .

\section{Analisis elastisitas produksi}

Pengaruh faktor produksi dapat diketahui dari nilai elastisitas produksi pada masing-masing faktor produksi yang digunakan. Nilai koofesien regresi dari model fungsi Cobb Douglas sekaligus menunjukkan besaran elastisitas produksi untuk masing-masing variabel penjela.

Hijauan. Dari hasil uji t diketahui bahwa jumlah konsumsi hijauan berpengaruh nyata terhadap tingkat produksi artinya tinggi rendahnya jumlah produksi susu sangat ditentukan oleh jumlah hijauan yang dikonsumsi. Nilai kooefisien regresi untuk variabel hijauan yang positif menunjukan pengaruh yang searah artinya jumlah produksi susu akan meningkat apabila jumlah hijauan yang dikonsumsi meningkat.

Nilai elastisitas produksi hijauan sebesar 1,671 berarti apabila jumlah hijauan yang dikonsumsi meningkat sebesar $1 \%$ akan memberikan dampak meningkatnya produksi susu sebesar $1,671 \%$, hal ini menunjukkan bahwa konsumsi hijauan berada pada daetah produksi I dalam fungsi produksi. Karena nilai peningkatan produksi lebih besar dari nilai peningkatan input dikatakan elastisitas hijauan pada perusahaan ini bersifat elastis dan pemberian hijauan secara teknis belum mencapai tingkat yang efisien, sesuai dengan pendapat Beattic dan Taylor (1994), yang menyatakan jika elastisitas produksi lebih besar dari satu berarti keuntungan maksimum belum tercapai karena produksi masih dapat ditingkatkan dengan cara menambah pemakaian input. Hal ini berarti pihak perusahaan masih bisa meningkatkan keuntungan dengan menambah jumlah hijauan yang dikonsumsi ratarata $5 \mathrm{Kg}$ /ekor sapi.

Konsentrat. Konsumsi konsentrat ratarata adalah $47,02 \mathrm{Kg}$ perminggunya. Uji statistik yang dilakukan menunjukkan variabel konsentrat tidak berpengaruh nyata dan positif terhadap produksi susu. Tak berpengaruh nyatanya variabel jumlah konsumsi konsentrat terhadap tingkat produksi disebabkan karena tidak terlalu bervariasinya jumlah konsentrat yang diberikan. Nilai koefisien yang positif menunjukan penambahan jumlah konsentrat akan meningkatkan tingkat produksi,

Koefesien regresi dari konsentrat adalah sebesar 0,405 yang berarti kenaikan pemberian konsentrat sebesar $1 \%$ akan meningkatkan produksi susu sebesar $0,405 \%$ ini berarti konsumsi konsentrat berada pada daerah produksi II (daerah rasional), dalam arti kata secara teknis konsumsi konsentrat telahefisien.

Bulan Laktasi. Menurut Sutardi (1982), tingkat produksi susu akan rendah pada bulan bulan laktasi awal selanjutnya akan meningkat hingga mencapai maksimum pada bulan laktasi kedua dan setelah itu meluncur turun sehingga mencapai titik rendah pada bulan laktasi kedelapan sampai kesepuluh. Dari keterangan di atas maka bulan laktasi juga merupakan salah satu variabel yang menentukan tinggi rendahnya produksi susu yang dihasilkan.

Pada saat penelitian dilakukan bulan laktasi sapi rata-rata bulan ke tujuh. Hasil uji statistik yang dilakukan menunjukkan hubungan antara produksi susu yang dihasilkan dengan bulan laktasi berpengaruh nyata dan negatif pada tingkat kepercayaan $99 \%$.

Nilai koofesien regresi bulan laktasi adalah $-0,187$ yang berarti semakin tinggi bulan laktasi seekor sapi maka produksi susu yang dihasilkan akan semakin rendah. $\mathrm{Hal}$ ini berarti bertambahnya bulan laktasi sebesar satu bulan dari bulan keđua maka produksi susu akan turun sebesar $0,187 \%$.

Berat Tubuh Sapi. Menurut Syanief dan Sumaprastowo (1984), sapi yang besar dapat menghasilkan susu yang lebih banyak dibandingkan dengan sapi yang kecil walaupun dari bangsa dan umur yang sama. Hal ini disebabkan karena sapi yang besar makannya lebih banyak dan ambingnya lebih besar sehingga memungkinkan produksi yang lebih tinggi. Dari hasil pendugaan model terlihat variabel berat tubuh sapi tidak berpengaruh nyata terhadap produksi susu artinya perbedaan berat tubuh sapi tidak signifikan pengaruhnya terhadap variasi produksi susu.

Nilai koofesien yang positif sebesar 0,119 untuk berat badan menunjukkan produksi akan meningkat seiring mening-katnya berat badan sapi 
Vol 13(1)

Tabel 2. Perbandingan NPM dan BKM Masing-masing Faktor Produksi

\begin{tabular}{lccrc}
\hline Faktor Produksi & $\begin{array}{c}\text { Rata-Rata Konsumsi } \\
(\mathrm{Kg})\end{array}$ & NPM ( Rp) & BKM (Rp) & NPM/BKM \\
\hline Hijauan & 209,46 & 1.920 & $150 / \mathrm{Kg}$ & 12,8 \\
Konsentrat & 47,02 & 2.080 & $1.200 / \mathrm{Kg}$ & 1,73 \\
\hline
\end{tabular}

Keterangan : $\mathrm{PY}=\mathrm{Rp} 4.000$ per liter

Sumber : Hasil Penelitian, 2009

artinya sapi dengan bobot yang berat produksi susunya juga relatif lebih tinggi. Apabila berat badan sapi meningkat sebesar $1 \%$ maka produksi susu akan meningkat sebesar $0,119 \%$.

\section{Analisis Efisiensi Ekonomi Penggunaan}

Faktor Produksi. Tujuan utama pemeliharaan sapi perah adalah untuk menghasilkan keuntungan yang maksimum dan meminimalkan biaya produksi. Maksimisasi keuntungan dapat dicapai dengan đua cara yaitu dengan memaksimumkan produksi pada tingkat penggunaan input yang sama dan yang kedua dengan meminimalkan penggunaan faktor produksi pada tingkat produksi yang sama. Minimalisasi biaya dapat ditentukan dengan dua cara yaitu memaksimumkan output pada tingkat biaya faktor produksi yang same dan yang kedua dengan meminimalkan biaya faktor produksi pada tingkat produksi yang sama.

Nilai efisiensi ekonomi dapat dilihat dari rasio antara nilai produk marjinal (NPM) dan biaya korbanan marjinal (BKM). NPM diperoleh dari hasil perkaltan antara harga produk dan tambahan hasil produksi. Nilai BKM diperolch dari harga masing-masing faktor produksi. Secara ekonomis, produksi dikatakan efisien apabila produksi tersebut memiliki rasio NPM dan BKM sama dengan satu untuk seluruh faktor produksi yang digunakan (Kareemet al., 2008).

Dari hasil pendugaan model didapat nilai produk marginal (NPM) dari hijauan sebesar Rp 1.920 yang artinya setiap pcnambahan $1 \mathrm{Kg}$ hijauan akan menambah penerimaan peternak sebesar $\mathrm{Rp}$ 1920. Harga hijauan adalah Rp $150 / \mathrm{Kg}$. Ratio NPM dan BKM sebesar 12,8 yang artinya hijauan masih dapat ditambahkan hingga mencapai kondisi optimal yaitu sebanyak $5 \mathrm{Kg} / \mathrm{ekor}$.

Nilai produk marginal dari konsentrat sebesar Rp 2.080 yang berarti penambahan pemberian konsentrat sebesar $1 \mathrm{Kg}$ akan menambah penghasilan peternak sebesar $\mathrm{Rp} 2.080$. Harga konsentrat perkilogramnya sebesar Rp 1.200 sedangkan ratio antara NPM dan BKM kosentrat sebesar 1,73. Hal ini berarti konsentrat secara ekonomis pada Peternakan Ompie Farm masih belum efisien.

\section{Ekonomi Skala Usaha Peternakan Sapi Perah Ompie Farm}

Ekonomi skala usaha (Return To Scale) perlu diketahui guna melihat apakah kegiatan suatu usaha yang diteliti mengikuti kaidah increasing return to seale, decreasing return to scale atau constant return to scale (Soekartawi, 1994).

Selanjutnya Soekartawi (1994) juga menjelaskan bahwa besaran elastisitas produksi sekaltgus menunjukkan tingkat skala usaha yang mana terdapat tiga kemungkinan antara input dan output yaitu :

1. Decreasing return to scale, bila proporsi penambahan input lebih besar dari proporsi penambahan output.

2. Constant return to scale, bila proporsi penambahan inputsama dengan proporsi penambahan output.

3. Increasing return to scale, bila proporsi penambahan inputakan menghasilkan tambahan outputyang proporsinya lebih besar.

Kay (1981), menyatakan bahwa kondisi skala usaha dapat ditentukan dengan menguji apakah $\sum \mathrm{bi}=1$ atau $\sum \mathrm{bi}=1$ (Increasing/ derceasing return to scale), penelitian ini didapat $\Sigma$ $\mathrm{bi}=2,076$ yang berarti skala usaha yang dijalankan berada dalam kondisi Increasing retum to scale yang berarti penambahan input akan menghasilkan tambahan outputyang proporsinya lebih besar. Hal ini sesuai dengan pembahasan sebelumnya dimana 
pemberian hijauan belum efisien baik secara teknis maupun secara ekonomis dimana dengan nilai elastisitas produksi besar dari satu maka keuntungan masih bisa ditingkatkan dengan menambah pemberian hijauan.

Dari hasil penelitian dapat dilihat bahwa untuk usaha petemakan sapi perah pada Peternakan Ompie Farm, produksi susunya $72,1 \%$ dipengaruhi oleh hijauan dan konsentrat yang dikonsumsi, bulan laktasi dan berat badan sapi. Hasil uji F menunjukkan bahwa secara keseluruhan variabel bebas berpengaruh sangat nyata terhadap produksi susu $(p<0,01)$. Hasil uji t menunjukkan variabel hijauan dan bulan laktasi berpengaruh nyata pada kepercayaan $99 \%$ sedangkan variabel konsentrat dan berat badan sapi berpengaruh tidak nyata. Peternakan sapi perah Ompie Farm berada pada kondisi increasing return to scale, Hal ini dapat dilihat dari nilai $\Sigma$ bi yang didapat sebesar 2,076. Oleh sebab itu Petemakan Ompie Farm masih bisa meningkatkan keuntungannya dengan cara menambahkan faktor produksi dalam proporsi yang tetap.

\section{KESIMPULAN}

Berdasarkan hasil dan pembahasan maka kesimpulan yang dapat diambil yaitu:

1. Variasi produksi susu pada Peternakan Sapi Perah Ompie Farm sebesar $72,1 \%$ dapat dijelaskan oleh variabel hijauan yang dikonsumsi, jumlah konsentrat yang dikonsumsi, bulan laktasi dari tiap-tiap ekor sapi dan perbedaan berat badan dari setiap ekor sapi. Variabel yang berpengaruh nyata pada tingkat prođuksi adalah jumlah hijauan yang dikonsumsi dan perbedaan bulan laktasi.

2. Pemberian hijauan belum efisien baik secara teknis maupun secara ekonomis sehingga keuntungan masih bisa di-tingkatkan dengan menambah kon-sumsi hijauan. Sedangkan konsentrat telah efisien secara teknis dan belum efisien secara ekonomis.

3. Ekonomi skala usaha berada dalam kondisi increasing return to scale yang berarti penambahan input menghasilkan tambahan output yang proporsinya lebih besar, hal ini dapat dilihat dari jumlah elastisitas produksi sebesar 2,076 .

\section{DAFTAR PUSTAKA}

Bakar, H. 1992. Ilmu ternak sapi perah. Laporan Penelitian. Universitas Andalas, Padang.

Beattie, B.R dan C.R. Taylor 1994. Ekonomi Produksi, Terjemahan Soeranto Joso Hardjono. Gadjah Mada University Press, Yogyakarta.

Busboom, J.R., T.I. Wahl, and G. D. Snowder. 1999. Economics of callipyge lamb production. J.Anim. Sci. 77:243-248.

Dinas Peternakan Provinsi Sumatera Barat. 2008. Sumatera Barat dalam Angka. Dinas Peternakan Provinsi Sumatera Barat, Padang.

Ferson, W., S. Sarkissian, and T. Simin. 2003. Spurious regressions in financial economics, J. Finance 58:1393-1413.

Hadley, D. 2006. Patterns in technical efficiency and technical change at the farm-level in England and Wales, 1982-2002. J. Agric. Econ. 57:81-100.

Kareem, R., A.O. Dipeolug; A.B. Aromolaran, and A Samson. 2008. Analysis of technical, allocative and economic efficiency of different pond systems in Ogun State, Nigeria, African J. Agric. Res. 3:246-254.

Mandaka, S. dan Parulian H. 2005. Analisis Fungsi Keuntungan, Efisiensi Eko-nomi dan Kemungkinan Skema Kredit bagi Pengembangan Skala Usaha Petenakan Sapi Perah Rakyat Di Kelurahan Kebon Pedes Kabu-paten Bogor. Jurnal Agro Ekonomi. Vol 23 (2) : Oktober: 191-208.

Simatupang, P. 1988. Penentuan skala usaha dengan fungsi keuntungan: landasan teoritis dengan contoh fungsi Cobb-Douglas dan translog. Jumal Agro Ekonomi, 7(1): 1-16.

Syarief, M.Z dan R.M. Sumaprastowo. 1984. Ternak Perah, Cet. 2. CV. Yasaguna, Jakarta.

Soekartawi. 1994. Teori Ekonomi Produksi dengan Pokok Bahasan Analisis Fungsi Produksi Cobb Douglas. Rajawali Press, Jakarta.

Sudono, A. R.F. Rosdiana, dan B. S. Setiawan. 2003. Beternak Sapi Perah Secara Intensif. PT. Agromedia Pustaka, Jakarta. 
Suresh, A., D.C. Gupta, and I. S. Mann. 2008. Returns and economic efficiency of sheep farming in semiarid regions: A study in Rajasthan. Agric. Econ. Res. Rev. 21:227-234.

Suryana, A. 1987. Keterbatasan fungsi Cobb-Douglas dalam pendugaan elastisitas permintaan input. Jurnal Agro Ekonomi, 6(1): 19-28.

Sutardi, T. 1982. Sapi Perah dan Pemberian Makanannya. Fakultas Peternakan Institut Pertanian Bogor, Bogor. 